\title{
Vegetation of Two Relict Mesas in Zion
} National Park

\author{
MICHAEL H. MADANY AND NEIL E. WEST
}

\begin{abstract}
Twelve permanent vegetation sampling plots were established on Greatheart and Church mesas in Zion National Park, Utah. Both relict mesas are surrounded by cliffs but contain the same variety of soil conditions as the nearby "mainland." The mesa vegetation was segregated into the following broad community types: mixed conifer forest, ponderosa pine savanna, Gambel oak woodland, pinyon woodland, snowberry-sagebrush steppe, and oak-sagebrush shrubland. Cover of all species was measured in the plots, in addition to tree stem density. Relationships of each community type to topo-edaphic factors and response to fire are noted. The mesa ecosystems can be used as standards to gauge the various effects of resource exploitation on analogous "mainland" areas.
\end{abstract}

Relict areas are of value to wildland managers as points of reference against which to gauge successional changes induced by land use activities. Perceptions of the degree of human modification are sharpened by such comparison, which lends an important historical perspective to the land quality evaluation process. Changes in ecosystem structure have a direct bearing on the amount of forage produced, in addition to affecting other wildland values such as watershed quality, timber production, and wildlife habitat. Knowledge of relict ecosystems can assist managers in planning activities by illustrating different resource levels than are found in the more prevalent, modified landscapes. Potential for range improvement can be predicted with greater accuracy if careful consideration is given to relict areas within the region of interest.

The relicts under consideration in this paper, Greatheart and Church Mesas, are but 2 of nearly 40 mesas in the high dissected confines of Zion National Park, Utah (Fig. 1). All of these mesas have a fairly level, vegetated summit related to the presence of the Temple Cap and/or Carmel Formation (Hamilton 1978).

Zion National Park lies on the western margin of the Colorado Plateau, a region that contains many isolated, and hence pristine, mesas. However, most studies of relict mesas in the Colorado Plateau have focused on ecosystems more typical of lower elevations, i.e., pinyon-juniper woodland, sagebrush shrubland, or desert grassland (Jameson et al. 1962; Schmutz et al. 1967; Mason et al. 1967; Kleiner and Harper 1972, 1977a, 1977b). Studies of relict mixed conifer (Abies-Pseudotsuga-Pinus) forest, ponderosa pine (Pinus ponderosa) forests or savannas, and Gambel oak (Quercus gambelii) woodlands have apparently been limited to Mason and West's (1970) report of a brief visit to Timber Top Mesa inside the Kolob Section of Zion National Park (Mason and West 1970). These authors reached this heretofore inaccessible mesa by helicopter and noted fire evidence in the mountain brush community (dominated by Gambel oak), ponderosa pine forest, and Douglas fir (Pseudotsuga menziesii) forest. No wildlife species larger than a chipmunk (Eutamias sp.) were seen on the mesa. Since Timber Top Mesa is bounded on all sides by sheer cliffs, it is apparently unvisited by large herbivores like mule deer (Dama

Authors are instructor and professor, respectively, Department of Range Science, Utah State University, Logan 84322.

This study was funded by the National Park Service, U.S. Department of Interior, through the NPS-USU Cooperative Studies Unit.

The authors wish to thank John Madany for the use of his photograph in Figure 3.

Manuscript accepted January 3, 1984.

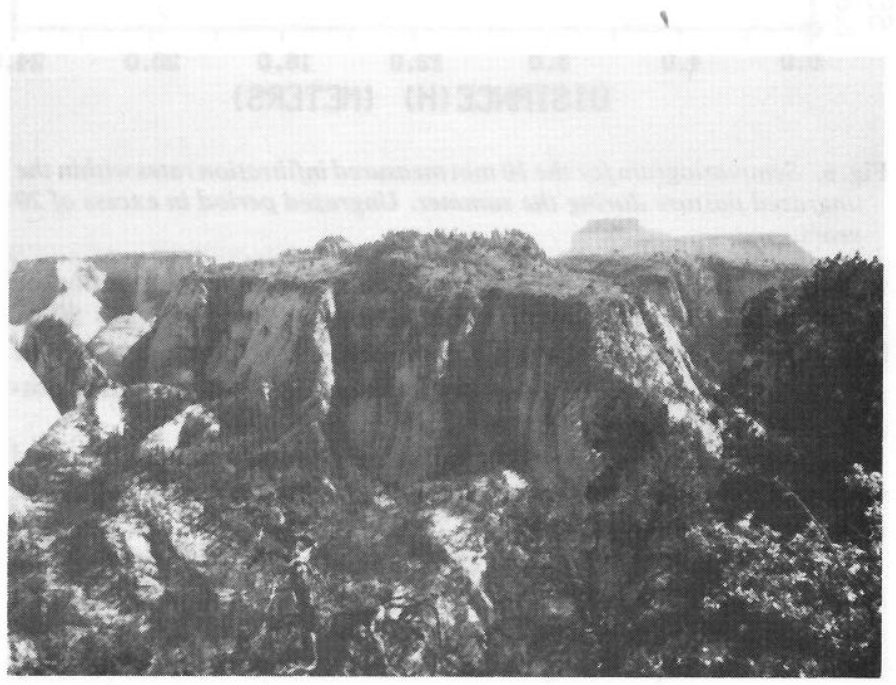

Fig. 1. Church Mesa as seen from the southern tip of the Horse Pasture Plateau. The vegetated summit is encircled by 150-300 $\mathrm{m}$ high cliffs.

hemionus hemionus (Rafinesque)). This situation lowers the value of the vegetation structure for comparison purposes, since it did not develop with the type of browsing pressure that characterized normal "mainland" systems in pre-European times. Mule deer signs have been observed on both mesas in our study.

This paper describes the vegetation on Greatheart and Church mesas. Its purpose is to provide a clearer picture of presettlement conditions of mid-elevation plateaus of southwestern Utah.

\section{Description of Study Area}

Greatheart and Church mesas are located in the center of Zion National Park (Fig. 2). Greatheart Mesa is $1 \mathrm{~km}$ west of the Horse Pasture Plateau and is 85 ha (210 acres) in size. Church Mesa (an unofficial name not yet on USGS maps) lies $2 \mathrm{~km}$ south of the Horse Pasture Plateau and $2 \mathrm{~km}$ west of the Zion Lodge. Church Mesa is 150 ha (370 acres) in size.

The vegetated summits of Greatheart and Church mesas lie between the elevations of $2,160 \mathrm{~m}(7,092 \mathrm{ft})$ and $2,259 \mathrm{~m}(7,410 \mathrm{ft})$, and $2,150 \mathrm{~m}(7,058 \mathrm{ft})$ and $2,254 \mathrm{~m}(7395 \mathrm{ft})$, respectively. The higher parts of the mesa tops are capped with limestone from the Carmel Formation. The remainder of each vegetated summit is underlain by sandstone and shales of the Temple Cap Formation (Hamilton 1978). The sheer 150- to $300-\mathrm{m}$ (500 to 1,000 ft) cliffs that circumscribe the 2 relicts are carved from Navajo sandstone.

Soils on the ridgetops are in the Paunsaugunt gravelly silt loam series, while the slopes are covered by the deeper Kolob-Detra association. Level areas near the rim of the mesas feature Kinesava fine sandy loam (Madany 1981). Soils of Zion National Park are described in more detail by Mortensen et al. (1977).

The mesas are covered by vegetation quite similar in general composition to that of the nearby Markagunt Plateau. Ponderosa 
much higher proportion of the flora was in identifiable condition.

Two permanent vegetation sampling plots were established on Greatheart Mesa and 10 were placed on Church Mesa (Fig. 2). All plots had a metal reinforcement bar placed at the northeast corner. Each $20 \times 15-\mathrm{m}$ plot was subjectively located in a homogenous portion of vegetation. All plots were chosen to correspond with the physical variables of objectively chosen sampling points on the nearby Horse Pasture Plateau (Madany 1981, Madany and West 1983). At each plot, the physical environment was quantified by measuring elevation and slope and assigning various categories such as topographic position, bedrock, and soil type. All tree stems greater than 5-cm dbh were recorded by species and size class for the entire plot. Cover of saplings, shrubs, forbs, and graminoids was visually estimated by species in each of $45 \times 5-\mathrm{m}$ subplots at the corner of the main plot. Increment cores were taken from several trees in each plot.

Nine partial cross-sections of fire-scarred ponderosa pine were cut on Church Mesa using the methods outlined by Arno and Sneck (1977). Descriptive notes were made concerning ecological conditions of the 2 mesas. Numerous color slides and black-andwhite photographs were taken to document conditions.

\section{Results and Discussion}

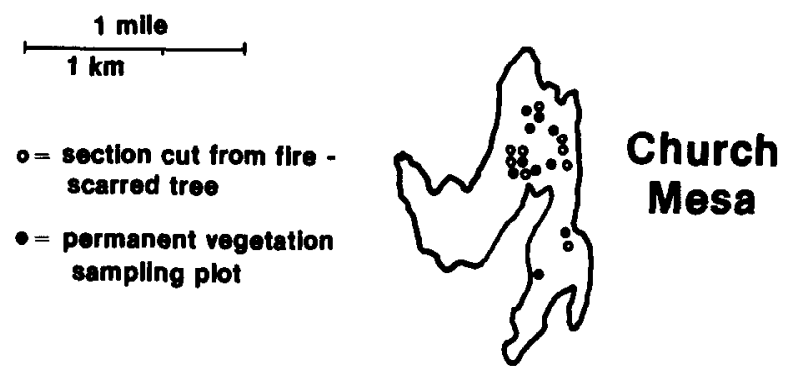

Fig. 2. Location of sampling points for vegetation plots and fire scarred trees in the study area.

pine, Gambel oak, Douglas fir, pinyon pine (Pinus edulis), white fir (Abies concolor), Rocky Mountain juniper (Juniperus scopulorum), and bigtooth maple (Acer grandidentatum) are the major trees in the study area. Common shrubs are Utah serviceberry (Amelanchier utahensis), greenleaf manzaniza (Arctostaphylus patula), mountain snowberry (Symphoricarpos oreophilus), and big sagebrush (Artemisia tridentata). Important grasses include muttongrass (Poa fendleriana), Indian ricegrass (Oryzopsis hymenoides), squirreltail (Sitanion hystrix), needle-and-thread (Stipa comata), Letterman needlegrass (Stipa lettermanii), and blue grama (Bouteloua gracilis). Nomenclature for vascular plants follows Nelson (1976).

Mule deer droppings, tracks, and antlers were seen on both mesas. Cougar (Felis concolor kaibabensis (Nelson and Goldman)) tracks, and a possible den, were found on Church Mesa. No permanent water was found on either mesa, although a seepage spring was seen on Church Mesa. Presumably, large mammals would have to leave the mesa regularly to obtain drinking water. The high elevation precludes year-round use by mule deer. The presence of large mammals in these relict areas adds to the comparison value of the vegetation since they developed under browsing pressure from the same species as on the "mainland." Diggings of what were presumed to be pocket gophers (Thomomys sp.) were also seen on Church Mesa.

\section{Methods}

Greatheart Mesa was visited by helicopter on November 4, 1978. Thus, the vegetation sampling that took place there did not register the presence of some of the more ephemeral forb species. Three days were spent on Church Mesa (August 15-17, 1979) when a

The 12 sampling plots were subjectively grouped into 5 cover types based on the dominant species in the upper-most strata of the community. These units are mixed conifer forest, ponderosa pine savanna, Gambel oak woodland, pinyon pine woodland and snowberry-sagebrush steppe. For each of these units, the constancy (where more than I plot was sampled), average cover, and density (for trees) will be presented. Remarks are also made pertaining to edaphic affinities, response to fire, and general structure.

\section{Mixed Conifer Forest}

Table 1 summarizes vegetation data for this very limited vegetation unit found only on shaded northern and eastern slopes. In the sample plot, white fir was the only conifer; however, in other locations Douglas fir and ponderosa pine made up part of the canopy. Three white fir and 1 Gambel oak were cored, giving the following ages: 102, 125, 173, and 116 years, respectively. There was no direct evidence that the most recent fire of 1964 had burned this particular stand. The understory of this stand was dominated by small Gambel oak and mountain snowberry. For details on the effects of fire in an extensive area of mixed conifer forest on a mesa just north of Church Mesa, see Madany (1981). Mixed conifer forest stands on the Horse Pasture Plateau tend to occur in similar topo-edaphic situations.

\section{Ponderosa Pine Savanna}

All communities dominated by ponderosa pine that were visited on Church and Greatheart mesas possessed a savanna physiognomy with a discontinuous canopy and a herbaceous-dominated groundlayer (Fig. 3). No closed forests were seen in contrast with the prevalent situation on the nearby Horse Plateau (Madany 1981, Madany and West 1983). A variety of edaphic conditions support ponderosa pine savanna. These include level areas near the rims of both mesas on soils (probably Kinesava fine sandy loam) derived from Temple Cap sandstones and shales; a north-facing slope of $15-20^{\circ}$ on Church Mesa on soils of the Kolob-Detra association; and shallower, gravelly sites on Paunsaugunt gravelly silt loam along the central ridgetop of Church Mesa underlain by limestone of the Carmel Formation.

The canopy was composed almost entirely of ponderosa pine ranging in age from 100 to 360 years. A few scattered Rocky Mountain or Utah junipers, white firs, or Douglas-firs were seen occasionally. Several regeneration groves of ponderosa pine of approximately 60 years of age were seen on Church Mesa. These presumably date from the 1919 generation that is so widespread throughout the Southwest (Arnold 1950). However, nowhere was 
Table 1. Species contributions to constancy $(\%)$, cover $(\%)$ and tree density (stems/ha) for five plant community types on two isolated mesas in Zion National Park.

\begin{tabular}{|c|c|c|c|c|c|c|c|c|c|c|c|c|}
\hline \multirow{3}{*}{$\begin{array}{l}\text { Growth form } \\
\text { Species }\end{array}$} & \multirow{2}{*}{\multicolumn{3}{|c|}{$\begin{array}{l}\text { Mixed conifer forest } \\
\text { (1 plot) }\end{array}$}} & \multirow{2}{*}{\multicolumn{3}{|c|}{$\begin{array}{l}\text { Ponderosa pine savanna } \\
\text { ( } 7 \text { plots) }\end{array}$}} & \multicolumn{3}{|c|}{ Plant Community Types } & & & \multirow[b]{2}{*}{$\begin{array}{l}\text { Snowberry-sage- } \\
\text { brush steppe } \\
\text { (1 plot) }\end{array}$} \\
\hline & & & & & & & \multicolumn{3}{|c|}{$\begin{array}{c}\text { Gambel oak woodland } \\
\text { ( } 2 \text { plots })\end{array}$} & \multicolumn{2}{|c|}{$\begin{array}{l}\text { Pinyon } \\
\text { woodland } \\
\text { (1 plot) }\end{array}$} & \\
\hline & constancy & cover & density & constancy & cover & density & constancy & cover & density & cover & density & cover \\
\hline \multicolumn{13}{|l|}{ Trees } \\
\hline Abies concolor & & 75 & 400 & 14 & 3 & 14 & & & & & & \\
\hline Quercus gambelii & & 30 & 333 & 14 & 1 & 5 & $x^{2}$ & 76 & 617 & & & \\
\hline Juniperus osteosperma & & & & 14 & i & 5 & & & & & & \\
\hline Juniperus scopulorum & & & & 14 & 4 & 10 & & & & & & \\
\hline Pinus ponderosa & & & & 100 & 33 & 129 & & & & & & \\
\hline Acer grandidentatum & & & & & & & & 15 & 233 & & & \\
\hline Pinus edulis & & & & & & & & & & 30 & 200 & \\
\hline \multicolumn{13}{|l|}{ Saplings/Shrubs } \\
\hline Symphoricarpos oreophilus & & 42 & & 86 & 9 & & & $\mathbf{x}$ & 42 & & & 20 \\
\hline Quercus gambelii & & 29 & & 71 & 14 & & $\mathbf{x}$ & 25 & & 22 & & 1 \\
\hline Acer grandidentatum & & 8 & & 14 & $\mathrm{~T}$ & & & 1 & & & & \\
\hline Amelanchier utahensis & & 1 & & 29 & $i$ & & & $\mathbf{T}$ & & 30 & & \\
\hline Pachistima myrsinites & & $i$ & & 14 & $\mathbf{T}$ & & & & & & 1 & \\
\hline Prunus virginiana & & $\mathbf{T}^{1}$ & & 29 & $\mathrm{~T}$ & & & 3 & & & & 2 \\
\hline Berberis repens & & & & 71 & 1 & & & $\mathrm{~T}$ & & & & \\
\hline Juniperus scopulorum & & & & 14 & $\mathbf{T}$ & & & & & 1 & & \\
\hline Abies concolor & & & & 14 & 2 & & & $T$ & & & & \\
\hline Artemisia tridentata & & & & 14 & 2 & & & & & & & 14 \\
\hline Chrysothamnus viscidiflorus & & & & 29 & 2 & & & & & & & 11 \\
\hline Petradoria pumila & & & & 29 & 2 & & & & & & & 11 \\
\hline Pinus ponderosa & & & & 14 & $T$ & & & & & & & \\
\hline Chrysothamnus nauseousus & & & & 14 & $\mathbf{T}$ & & & & & & & \\
\hline Rosa woodsii & & & & 14 & $\mathrm{~T}$ & & & & & & & \\
\hline Chrysothamnus depressus & & & & 14 & $\mathbf{T}$ & & & & & & & \\
\hline Ceanothus fendleri & & & & 14 & $\mathrm{~T}$ & & & & & & & \\
\hline Purshia tridentata & & & & 43 & 1 & & & & & & & \\
\hline Yucca augustissima & & & & 14 & 1 & & & & & & & \\
\hline Arctostaphylos patula & & & & 29 & 2 & & & & & 34 & & \\
\hline Cercocarpus montanus & & & & & & & & & & 18 & & \\
\hline Opuntia basilaris & & & & & & & & & & 2 & & \\
\hline Graminoids & & & & & & & & & & & & \\
\hline Bromus ciliatus & & $\mathbf{T}$ & & 43 & $\mathrm{~T}$ & & & & & & & \\
\hline Carex praegracilis & & & & 14 & 1 & & & $\mathbf{T}$ & & & & 2 \\
\hline Poa fendleriana & & & & 100 & 9 & & & 2 & & $\mathbf{T}$ & & 2 \\
\hline Sitanion hystrix & & & & 86 & 5 & & & 1 & & & & 1 \\
\hline Stipa lettermanii & & & & 57 & 3 & & $\mathbf{x}$ & 2 & & & & 3 \\
\hline Oryzopsis hymenoides & & & & 29 & 1 & & & & & $\mathrm{~T}$ & & $\mathrm{~J}$ \\
\hline Muhlenbergia montana & & & & 29 & 6 & & & & & & & 7 \\
\hline Stipa comata & & & & 57 & 4 & & & & & & & 47 \\
\hline Bromus tectorum & & & & 14 & 2 & & & & & & & \\
\hline Koeleria cristata & & & & 14 & $\mathbf{T}$ & & & & & & & \\
\hline Agropyron riparium & & & & & & & & 8 & & & & 5 \\
\hline Forbs & & & & & & & & & & & & \\
\hline Disporum trachycarpum & & $\mathbf{T}$ & & & & & & & & & & \\
\hline Phacelia heterophylla & & $\mathrm{T}$ & & 43 & 1 & & & $\mathrm{~T}$ & & & & \\
\hline Lathyrus leucanthus & & 1 & & 43 & 1 & & & $\mathrm{~T}$ & & & & \\
\hline Stellaria jamesiana & & 1 & & 29 & $\mathrm{~T}$ & & $\mathbf{x}$ & 4 & & & & $\mathbf{T}$ \\
\hline Polygonum douglasii & & & & 71 & 2 & & $x$ & $\mathbf{T}$ & & & & 4 \\
\hline Solidago multiradiata & & & & 43 & 6 & & & 3 & & & & 2 \\
\hline Artemisia ludoviciana & & & & 43 & 2 & & & 1 & & & & 1 \\
\hline Artemisia dracunculus & & & & 29 & 2 & & & 4 & & & & 5 \\
\hline Phlox austromontana & & & & 43 & 1 & & & & & $\mathbf{T}$ & & \\
\hline Senecio multilobatus & & & & 29 & 1 & & & 1 & & $\mathbf{T}$ & & \\
\hline Machearanthera linearis & & & & 57 & 1 & & & $\mathrm{~T}$ & & & & \\
\hline Eriogonum racemosum & & & & 57 & 1 & & $\mathbf{x}$ & $\mathrm{T}$ & & & & $\mathbf{T}$ \\
\hline Vicia americana & & & & 43 & 2 & & & & & & & 2 \\
\hline Cirsium pulchellum & & & & 43 & 1 & & & & & & & \\
\hline Arabis holboellii & & & & 43 & $\mathrm{~T}$ & & & & & & & \\
\hline Linum lewisii & & & & 43 & $\mathrm{~T}$ & & & & & & & \\
\hline Lomatum nuttallii & & & & 29 & 2 & & & & & & & \\
\hline Chrysopsis villosa & & & & 29 & 1 & & & & & & & \\
\hline Thermopsis montana & & & & 29 & 1 & & & 1 & & & & 2 \\
\hline Comandra umbellata & & & & 29 & $\mathbf{T}$ & & & & & & & \\
\hline Arenaria macredenia & & & & 29 & $\mathbf{T}$ & & & & & & & \\
\hline
\end{tabular}




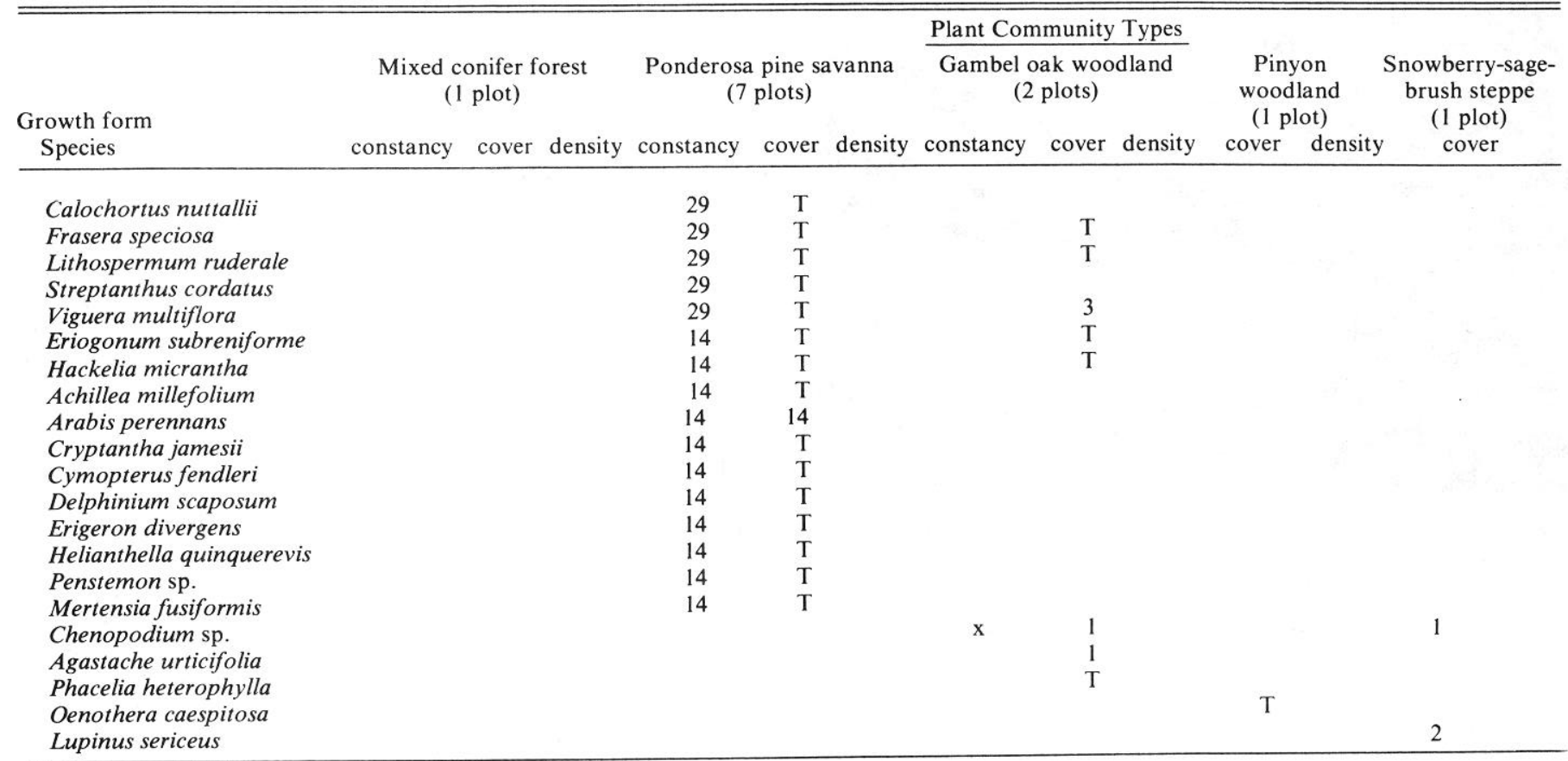

'T indicates a trace (less than $0.5 \%$ cover)

${ }^{2} \mathrm{x}$ indicates presence in both plots

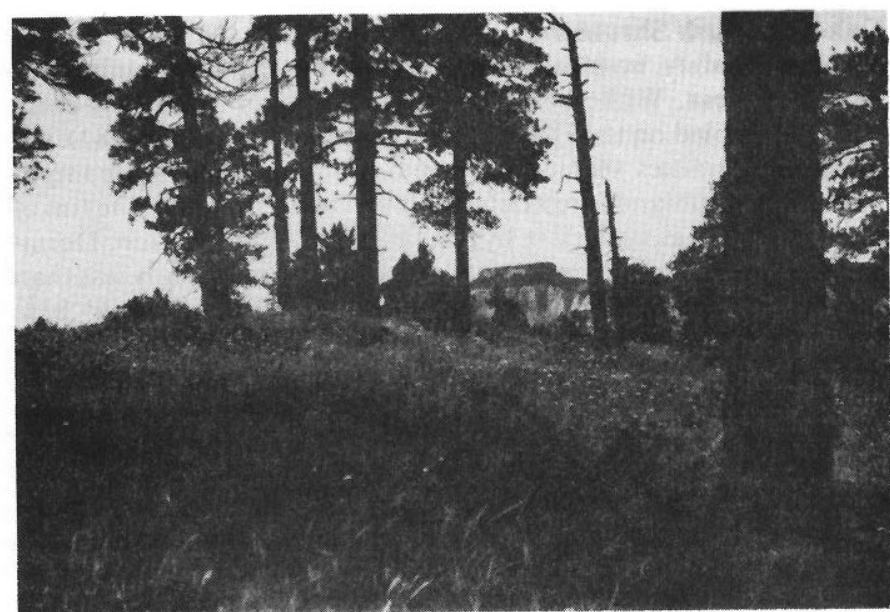

Fig. 3. The ridge crest on Church Mesa is covered by ponderosa pine savanna featuring a grass-dominated groundlayer. Squirreltail is visible in the foreground.

the continuous layer of pine stems of that age seen that characterize the understory of ponderosa pine forests on the mainland (Madany and West 1983).

As indicated in Table 1, only Gambel oak and mountain snowberry have a considerable amount of coverage in the shrublayer of this community type. A wide diversity of shrubs (17 species) were present, but nearly all had less than $2 \%$ cover. The effects of the most recent fire (in 1964) on the Church Mesa stands were quite evident. Utah serviceberry was diminutive in stature and only rarely were individuals seen that were over a meter in height. Greenleaf manzanita had not yet recovered even $50 \%$ of its pre-fire coverages, as evidenced by the comparison between skeletons killed by the 1964 fire and existing shrubs. Most oak and maple clones that had their aerial portion killed in the 1964 fire were vigorously resprouting. Fendler buckbrush (Ceanothus fendleri), while only occurring in 1 of the 7 plots, appears to be much more widespread and vigorous than on the Horse Pasture Plateau (Madany and West 1983) - a condition quite possibly linked with the 1964 fire. Tree saplings are scattered throughout the shrublayer, with white fir being locally common on the north slope of the central ridge on Church Mesa. These saplings presumably date from after 1964. A fire frequency interval of 69 years (with a range of 56 to 79) was determined from analysis of the 9 partial crosssections cut from fire-scarred pines. This is much lower than the 4 to 7 years frequency interval for the "mainland" Horse Pasture Plateau (Madany and West 1980).

The most important grasses, in terms of cover, are nearly all of the cool-season growth habit: muttongrass, squirreltail, needleand-thread, and Letterman needlegrass. Mountain muhly (Muhlenbergia montana) is the only warm-season grass of note. In contrast to the above-mentioned cool season grasses, mountain muhly is quite rare on the nearby Horse Pasture Plateau (Madany and West 1983). Among forbs, low goldenrod (Solidago multiradiata) is notable in its relatively high coverage. Cheatgrass (Bromus tectorum) was restricted in its occurrence to areas beneath juniper trees killed in the 1964 fire. Presumably, there were few herbs directly below the juniper before 1964. Following the intense heat generated by the burning juniper, the cheatgrass apparently invaded to occupy the sterilized soil. The appearance of this alien, several kilometers from the nearest mainland seed source can be either attributed to animal vectors or wind dispersal.

\section{Gambel Oak Woodland}

This widespread community type covered at least $50 \%$ of both mesas and was found in the same general range of sites, and on similar soils, as the ponderosa pine savanna. As on the "mainland" (Madany and West 1983), the reasons why a particular spot is dominated by Gambel oak rather than ponderosa pine are unclear. The clonal habit of the oak produces a complex community patterning with mottes of the small tree interdigitating with grassland and savanna in intricate mosaic (Fig. 4). Sampling such a community was difficult since conditions directly beneath the canopy tended to be quite different (both physically and biotically) from the small openings that separate each motte. As a rule, shrubs and 


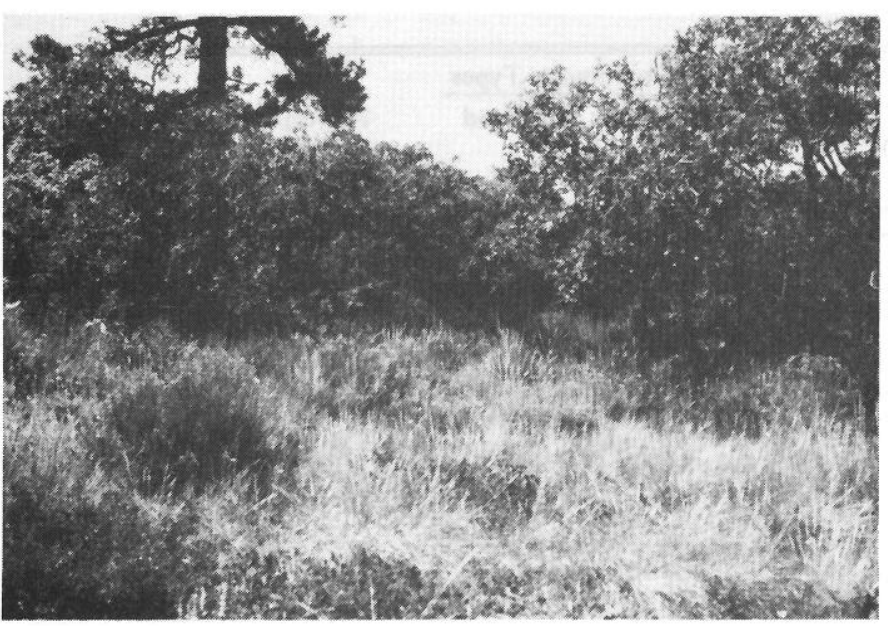

Fig. 4. Interspaces between mottes in the Gambel oak woodland are dominated by perennial bunchgrasses. The large tree in the background is an isolated specimen of ponderosa pine.

certain forbs are more prominent in the direct shade of the clone interior, while grasses dominated the interspaces. From the 3 oaks and 1 maple cored in the 2 stands (both on Church Mesa), the following ages were derived: $62,64,113$, and 65 years, respectively.

This woodland community is not as flammable as the savanna and snowberry-sagebrush steppe. On Church Mesa, a variety of responses of Gambel oak to fire were observed. Isolated clones surrounded by grass were killed to the ground and were vigorously resprouting. Areas of woodland that bordered on savanna or snowberry-sagebrush steppe showed evidence of burning with many of the lower branches being killed on the oak. Losses of entire mature stems ranged from about 10-30\%. Areas further away from more flammable communities did not appear to have burned. The presence of large stems of presumably more sensitive species like big-tooth maple and chokeberry (Prunus virginiana) in burned stands indicates that fires were both patchy and of low intensity. Fires probably burn into the Gambel oak woodland along the grassy interspaces, but eventually burn out in the moist fuels of the interior of oak mottes.

As can be seen in Table 1, the most prominent shrubby associate of Gambel oak in the shrublayer is mountain snowberry. A variety of herbaceous species is present, reflecting the physiognomic heterogeneity of the community. Streambank wheatgrass (Agropyron riparium), muttongrass, and Letterman needlegrass are especially characteristic graminoids. Tarragon (Artemisia dracunculus), tuber starwort (Stellaria jamesiana), low goldenrod, and showey goldeneye (Viguiera multiflora) are the most prevalent forbs.

\section{Pinyon Woodland}

This community occupies the driest sites on both mesas, favoring southern and western exposures, often in areas with bedrock outcrops. The sole stand sampled in our study was on a west-facing slope of $26^{\circ}$ on Greatheart Mesa. A fire had probably not burned the locale for a century or more. One pinyon was cored and yielded an age of 210 years. The dense understory was made up of Gambel oak, Utah serviceberry, greenleaf manzanita, and true mountain mahogany (Cercocarpus montanus). Since sampling was done in early November, the cover and number of herbaceous species is doubtless under-represented (Table 1). Nevertheless, the conclusion can be drawn that the pinyon woodland, like the mixed conifer forest, lacks a sizeable herbaceous groundlayer.

Unfortunately, a sample plot was not placed in this vegetation type on Church Mesa. However, several observations can be made. A number of mature pinyons killed in the 1964 fire were seen in both level, grassy, and steeper, rockier sites. Also, true mountain mahogany is lacking on Church Mesa. This anomaly is curious, as the shrub is found on both Greatheart Mesa and Burnt Mountain (a mesa $14 \mathrm{~km}$ to the northwest). The pinyon woodland type on Church Mesa is generally restricted to steeper sites than Greatheart Mesa, with corresponding sparser understory and groundlayer vegetation. The different fire histories of the 2 mesas may be one factor in effecting this condition.

\section{Snowberry-Sagebrush Steppe}

One plot was established in this community type on Church Mesa. The proper topographic conditions conducive to low shrub steppe development are apparently not found on Greatheart Mesa. This community type occupies a well-defined alluvial depression at the north end of Church Mesa that is between 5 and 10 ha in area. While an intermittent stream channel is shown dissecting this community on the official USGS topographic map (see Zion National History Association 1977), we did not find any visible channel at any point in the entire valley. By contrast, gullying and deeply incised channels are common phenomena in analogous valleys on the Horse Pasture Plateau.

Big sagebrush, mountain snowberry, and sticky-leaf rabbitbrush (Chrysothamnus viscidiflorus) are all present in youthful vigor. The sagebrush presumably has reproduced from seed following the 1964 fire that burned the entire valley, while the other 2 shrubs have resprouted. However, due to their low stature, the visual dominance is usurped by the grasses. From Table 1, one can see that needle-and-thread contributes nearly half of the cover of the community. The species richness and high coverage of the mesa community (when contrasted with similar sites on the plateau) is a situation which can probably be attributed to the better water relations of the undissected soil.

\section{Oak-Sagebrush Shrubland}

Unfortunately, no plots were established in this community type on either mesa. While being quite similar to an analogous community sampled on the Horse Pasture Plateau (Madany 1981), the mesa communities seemed to have a much higher grass component. This shrubland is restricted to level sandy soils near the rim of the mesa on areas underlain by the Temple Cap Formation. Dominance appeared to be shared between shrub form (usually less than $2 \mathrm{~m}$ ) Gambel oak, big sagebrush, needle-and-thread, and blue grama. This community occasionally merged into Gambel oak woodland or ponderosa pine savanna. The relative abundance of shrubs vis-a-vis grasses would seem to be mediated by the frequency of fire.

\section{Conclusion}

The results of the vegetation sampling conducted on the 2 mesas show the importance of perennial herbaceous species in the groundlayer of all but 2 rather minor vegetation types. This contrasts with conditions on the formerly grazed Horse Pasture Plateau (Madany 1981, Madany and West 1983). The savanna physiognomy of the ponderosa pine stands is quite similar to conditions described by Rummell (1951) and Franklin et al. (1982) on Meeks Table in central Washington. Accounts of various early explorers in the West give the impression that the typical structure of ponderosa pine communities was indeed savanna (Cooper 1960).

The results of studies of lower elevation mesas in Arizona and Utah (Jameson et al. 1962, Mason et al. 1967, Schmutz et al. 1967) were similar to those of our study. In fact, many of the same species of grass are dominant on the mesas they studied and this study area. The presence of these relicts complements and corroborates the historical accounts of the pristine vegetation before impacts of livestock grazing, logging, and fire control began. Declines in forage production, wildlife habitat quality, and watershed characteristics may be gauged by the careful comparison of these mesas and adjacent "mainland" areas. See Madany and West (1983) for a discussion of these issues. 
Current National Park Service policy regarding land management objectives is to restore, through a variety of approaches, ecosystems that have been affected by European man (Bonnicksen and Stone 1982). The data presented here can contribute to a comprehensive effort to restore pre-settlement conditions in the modified upper elevation ecosystems of Zion National Park.

\section{Literature Cited}

Arno, S.F., and K.M. Sneck. 1977. A method for determing fire history in coniferous forests in the Mountain West. USDA Forest Serv. Gen. Tech. Rep. INT-42. Int. Forest and Range Exp. Sta., Ogden, Utah.

Arnold, J.F. 1950. Changes in ponderosa pine-bunchgrass ranges in northern Arizona resulting from pine regeneration and grazing. J. Forest. 48:118-126.

Bonnicksen, T.M., and E.C.Stone. 1982. Managing vegetation within U.S. National Parks: a policy analysis. Environ. Manage. 6:109-122.

Cooper, C.F. 1960. Changes in vegetation, structure, and growth of southwestern pine forests since white settlement. Ecol. Monog. 30:129164.

Franklin, J.F., F.C. Hall, C.T. Dyrness, and C. Maser. 1972. Meek's Table Research Natural Area. P. ME1-ME11 In: Federal Research Natural Areas in Oregon and Washington. A guidebook for scientists and educators. USDA Forest Serv. PNW Forest and Range Exp. Sta., Portland, Ore.

Hamilton, W.L. 1978. Geological map of Zion National Park, Utah. Zion Natural History Ass., Springdale, Utah.

Jameson, D.A., J.A. Williams, and E.W. Wilton. 1962. Vegetation and soils of Fishtail Mesa, Arizona. Ecology 43:403-410.

Kleiner, E.F., and K.T. Harper. 1972. Environment and community organization in grasslands of Canyonlands National Park. Ecology 53:299-309.
Kleiner, E.F., and K.T. Harper. 1977a. Soil properties in relation to cryptogamic groundcover in Canyonlands National Park. J. Range Manage. 30:202-205.

Kleiner, E.F., and K.T. Harper. 1977b. Occurrence of four major perennial grasses in relation to cdaphic factors in a pristine community. J. Range Manage. 30:286-289.

Madany, M.H. 1981. Land use-fire regime interactions with vegetation structure of several montane forest areas of Zion National Park. M.S. Thesis, Utah State University, Logan.

Madany, M.H., and N.E. West. 1980. Fire history of two montane forest areas of Zion National Park. P. 50-56. In: Stokes, M.A., and J.H. Dieterich, technical coordinator. Proc. Fire History Workshop, October 20-28, 1980, Tucson, Ariz. USDA Forest Serv. Tech. Rep. RM-81.

Madany, H.H., and N.E. West. 1983. Livestock grazing-fire regime interactions within montane forests of Zion National Park, Utah. Ecology 64:661-667.

Mason, L.R., H.M. Andrews, J.A. Carley, and E.D. Haacke. 1967. Vegetation and soils of No Man's Land Mesa relict area, Utah. J. Range Manage. 20:45-49.

Mason, L.R., and N.E. West. 1970. Timber Top Mesa: A relict area in Zion National Park. Proc. Utah Acad. Sci., Arts. Letters 47:284-285.

Mortensen, V.L., J.A. Carley, G.C. Crandall, K.M. Donaldson, Jr., and G. Leishman. 1977. Soil survey of Washington County area, Utah. USDA Soil Conserv. Serv. Washington, D.C.

Nelson, R. 1976. Plants of Zion National Park. Zion National History Ass. Springdale, Utah.

Rummell, R.S. 1951. Some effects of livestock grazing on ponderosa pine forests and range in central Washington. Ecology 32:594-607.

Schmutz, E.M., C.C. Michaels, and B.I. Judd. 1967. Boysag Point: A relict area on the north rim of Grand Canyon in Arizona. J. Range Manage. 20:363-369.

Zion Natural History Association. 1977. Topographic map, Zion National Park, Utah. ZNHA, Springdale, Utah.

\title{
RANGELAND HYDROLOGY
}

\author{
by Farrel A. Branson, Gerald F. Gifford, Kenneth G. Renard, and \\ Richard F. Hadley
}

Unique in its emphasis on the hydrology of rangelands, primarily arid and semiarid lands. RANGELAND HYDROLOGY provides a text for one aspect of range management where none has existed before. This expanded Second Edition presents in-depth information for those who must manage rangeland or respond to questions about the impacts of land use practices on hydrology.

Included in the new Second Edition are a chapter on modeling with approaches to predicting the effects of land use, and a chapter on the rapidly developing field of snow pack management.

The 352-pages include 197 illustrations, providing rapid access to an assembly of data found nowhere else and useful in the preparation of environmental impact statements. Extensive bibliographic material with each chapter and a subject matter index add to the useableness of the book.

Range scientists and managers, soil conservationists, hydrologists, agricultural engineers, land reclamation specialists, wildlife managers, graduate and undergraduate students and their professors, as well as all interested in the hydrology of arid lands will find RANGELAND HYDROLOGY a valuable addition to their libraries. (352 pages paper laminated cover $\$ 15.00$ US) 